\title{
Human Hardjo leptospirosis detected in the Slovak Republic by using serum antibody absorption test
}

\author{
Bakoss $\mathrm{P}^{1}$, Hudecova $\mathrm{H}^{2}$, Jarekova $\mathrm{J}^{1}$, Perzelova $\mathrm{J}^{1}$ \\ Institute of Epidemiology, Faculty of Medicine, Comenius University, Bratislava, Slovakia. \\ pavol.bakoss@fmed.uniba.sk
}

\section{ABSTRACT}

OBJECTIVE: The study was aimed at the discovery of the possible presence of the human Hardjo leptospirosis in Slovakia.

BACKGROUND: Throughout the world, there is a considerable number of publications confirming the presence of this zoonotic infection in domestic animals. On the contrary, scarcely more than a dozen of reports dealing with this occupational disease in humans was published till now. Moreover, the results of them are not convincing in all cases.

MATERIAL AND METHODS: Patients' and dairy cattle serum samples with detected antibodies against the Leptospira strains belonging to four different serovars of the serogroup Sejroe known to be present in Slovakia (i. e. Sejroe, Istrica, Saxkoebing, Polonica) and also reacting with serovar Hardjo strains were examined by using the serum-agglutinin absorption tests in order to determine the etiological agent of the illness on serovar level. RESULTS: The Hardjo infection was unequivocally confirmed approximately in $1 / 5$ of patients'sera and in $3 / 5$ of dairy cattle sera.

CONCLUSION: The AATS are useful tools for detection of Hardjo leptospirosis what is a necessary condition for determination of appropriate epidemiological measures related to this occupational disease. As our knowledge, this methodological approach was not used by other authors till now (Tab. 4, Fig. 1, Ref. 19). Text in PDF www.elis.sk. KEY WORDS: Leptospira, serovar Hardjo, human disease, serological diagnostics.

\section{Introduction}

The exact determination of which serovar of agents causes leptospirosis is a basic requirement from the point of epidemiological and epizootological view and a basic condition for determination of appropriate control measures.

This principle is also valid for an important zoonosis caused by leptospires of the Hardjo serovar belonging to the Sejroe serogroup. In men the illness has mostly occupational character in dairy farm workers and is known as milkers' disease or dairy farm fever. The maintenance hosts of the infectious agent causing this disease are especially cattle and sheep but the infection also occurs in pigs and horses.

There exists a considerable number of earlier reports on the detection of this disease in domestic animals above all in cattle throughout the world including some European countries such as Italy, Great Britain, The Netherlands, Germany, Portugal, Switzerland, Hungary, Poland and Spain.

On the contrary, all over the world scarcely more than a dozen of publications dealing with the infection in humans was published

${ }^{1}$ Institute of Epidemiology, Medical Faculty, Comenius University, Bratislava, Slovakia, and ${ }^{2}$ Veterinary Clinic PLANET, Bratislava, Slovakia

Address for correspondence: P. Bakoss, MD, DSc, Institute of Epidemiology, Faculty of Medicine, Comenius University, Špitálska 24, SK-813 72 Bratislava, Slovakia.

Phone: +421.290119488 till now. The reason of this situation probably is that dairy workers are not easily infected with leptospires of the Hardjo serovar (1). In Europe, references concerning human Hardjo disease are known from The United Kingdom (2), Republic of Ireland (3), Italy (4), The Netherlands (5) and Austria (6). The diagnosis on serovar level in patients afflicted with this disease was mostly based on the results of MAT, ELISA and only rarely on PCR or culture of the agent. Therefore the data are not sufficiently convincing in all cases.

Till now, the infection was detected neither in animals nor in human beings in the Slovak Republic, where however, Leptospira strains of four other serovars belonging to the Sejroe serogroup, i.e. Sejroe (reference strain M 84), Istrica (Bratislava), Saxkoebing (Mus 24) and Polonica (493 Poland) are known to be present. Because the diseases caused by leptospires of these serovars cannot be distinguished on serovar level using merely MAT, these illnesses are, in the authors' laboratory, generally termed Sejroe group infections (designated sensu lato for this study). By reason of eventual discovery of Hardjo infection in Slovakia, the laboratory completed the usual MAT battery of the four mentioned Leptospira strains of the serogroup Sejroe also by the strain Hardjoprajitno.

Some years ago, sera of four rmilkers were successively sent to the authors' laboratory for diagnosing leptospirosis. They reacted not only with leptospires of the four mentioned serovars belonging to the Sejroe serogroup but also strongly agglutinated the strain Hardjoprajitno. Consequently, in intention to determine the causal Leptospira serovar these sera were more profoundly 


\section{1-176}

studied using serum agglutinin-absorption tests (AATs) which already revealed to be useful in the past. The present study deals with the obtained results.

\section{Material and methods}

\section{Microscopic agglutination test (MAT) and Leptospira strains}

In the first i.e. screening phase of MAT (initial dilution with the added antigen $=1: 100$ ) the usual battery of Leptospira strains was used. The battery encompassed pathogenic and saprophytic strains representing serological groups Icterohaemorrhagiae, Grippotyphosa, Sejroe, Javanica, Pomona, Canicola, Australis, Tarassovi, Bataviae, Ballum, Autumnalis, Pyrogenes, Andamana and Semaranga. The sera which strongly agglutinated the four mentioned strains of the serogroup Sejroe and also the strain Hardjoprajitno (Leptospira interrogans genetic subtype Hardjopratitno) were in the second, i.e. quantitative phase of the test diluted in geometrical progression and examined with these strains in order to determine their antibody levels. Later also the strain Grossbeeren of serovar Hardjo (L. borgpeterseni genetic subtype Hardjobovis) kindly provided by BGVV Berlin was added to MAT. Both serovar Hardjo strains reacted in serological tests identically what is in agreement with the older data (7).

\section{Agglutinin-absorption test (AAT)}

The AAT was performed with sera in the usual way as described before (8). For distinguishing among the causal serovars of leptospirosis the $10 \%$ criterion of the Subcommittee on the Taxonomy of Leptospira (9) was applied reversely, i.e. in opposite arrangement: For the causal Leptospira strain of the disease was considered that after absorption by which less than $10 \%$ of antibody titre of the unabsorbed patient's serum remained in repeated tests.

\section{Patient's sera}

For examination by AATs were used only sera positive in MAT at a titre $\geq 1: 6400$ with at least one of the mentioned Leptospira strains of the Sejroe serogroup, inclusive the Hardjoprajitno and/ or Hardjobovis strains; the latter two ones must have been positive either at the mentioned titre or, rarely, no less than to $25 \%$ of it.

The study started with examination by AATs of the sera of the four mentioned milkers coming from distant dairy farms (1st group of persons). Three of them presented illness - two manifested meningitis and the third only a feverish disease. The fourth person may have got over a very mild or even an asymptomatic infection as her seropositivity was detected accidentally in consequence of a preventive serological examination of workers on the dairy farm where the last mentioned woman worked. Afterwards sera of other 16 patients (2nd group) with Sejroe disease (sensu lato) from dairy farms also situated in different regions of the country sent to the author's laboratory for usual diagnostics of leptospirosis were examined at a later time by the same method.

Out of the total of 20 human serum samples examined by AATs, 10 were taken from men and 10 from women. Fifteen of them came from the west region of Slovakia, 2 from the midland, 3 from the east part of the country (Fig. 1). Fifteen of them were villagers, five lived in small towns. As for their profession, 6 were milk-maids, one milk-man, 5 pensioners, one animal-tender, one forester, one baker, one lathe-worker, one land-surveyor (geodesist), one pupil, one working man and one unemployed.

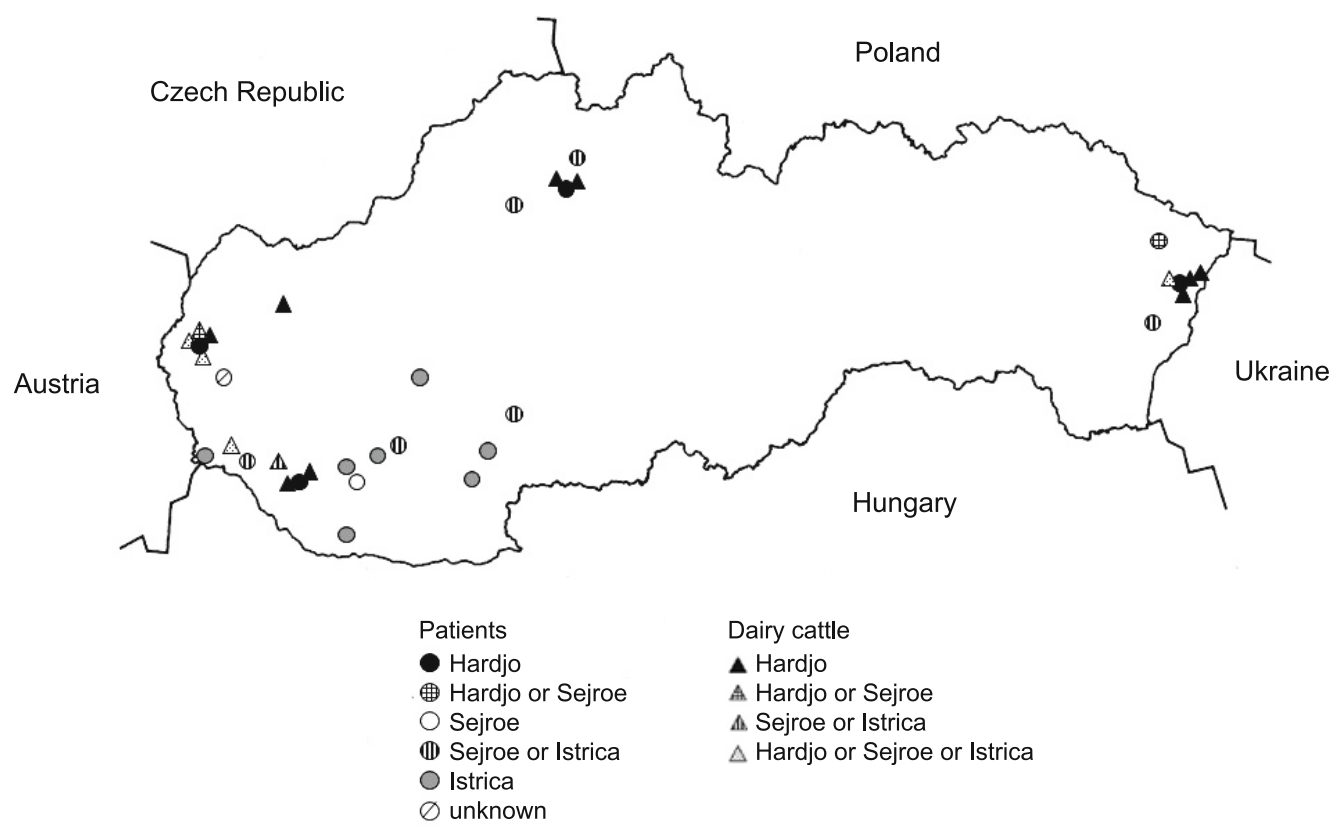

Results of AATs of each serum is marked separately

Fig. 1. Regional distribution of patients'and cows'sera on serovar level in Slovakia. 
Dairy cattle sera

Out of some dozens by MAT examined animal sera in the authors' laboratory, 52 revealed antibodies against Sejroe group leptospires. Sera of only 15 among them were suitable for AATs, their antibody titres reaching at least $\geq 1: 3200$ against the mentioned strains of the Sejroe group serovars including the serovar Hardjo. The sera came from 7 dairy farms situated in diverse parts of Slovakia. The majority of the sera, i. e. twelve, were taken from dairy cattle on the farms where the four Hardjo patients were detected. The rest of them were collected on dairy farms where no human leptospirosis was recorded at that time. Evaluation of the results obtained by AATs was identical with that of the patients' sera.

\section{Sera of small mammals}

In addition, sera of 44 small terrestrial mammals (the majority of them were members of the Mus musculus spp.), caught on the farm from which came the person with an asymptomatic Hardjo infection), were examined by MAT for the presence of Leptospira antibodies.

\section{Results and discussion}

Hardjo leptospirosis is an occupational zoonosis of those who work with domestic animals, particularly with cattle and sheepthe maintenance hosts of this infection. In spite of this, publications dealing with the disease in men are scarce worldwide and the laboratory diagnosis of the infection not convincing in all cases.

In Slovakia this infection was detected neither in animals nor in humans till now. Therefore a study was undertaken to discover whether human Hardjo disease occurs also in this country. Because the illness cannot be diagnosed on serovar level using merely usual MAT, AATs were used in this study. These tests were already found to be helpful to serological discrimination between the serum titre against the etiological agent and the co-agglutination(s), i. e. to differentiation of the type of illness on serogroup level. Moreover, the method was also available for discrimination between the cause of the illness on serovar level within the same serogroup (10-12).

\section{Patient's sera}

The study started with examination by AATs of four dairyworkers' sera (1st group of patients) which presented sufficiently high antibody titres to Leptospira strains of the used five serovars of the serogroup Sejroe, inclusive serovar Hardjo strain(s). The results of AATs proved Hardjo infection in all these examined persons. Typical results obtained with the serum of one of these patients are in Table 1: In repeated tests, antigens prepared from the four reference Leptospira strains of the serogroup Sejroe, for MAT usually used during many years in the authors' laboratory, were unable to completely absorb the antibodies while the antigen Hardjobovis did it. Virtually the same results were obtained with the sera of the other three patients.

Subsequent examination by the same method of the sera of other 16 patients with Sejroe illness (sensu lato) (2nd group) was undertaken. The sera were collected on diverse dairy farms, mostly those where the human Hardjo infections were diagnosed.

Unequivocal results, when only one of the absorbing five antigens was able to absorb all serum antibodies, were obtained in eight cases. They indicated in seven cases including the sera of two dairy-maids an illness due to the serovar Istrica and in one case a serovar Sejroe infection.

Such a clear serovar determination was not possible in other six sera (including one dairy-man sample) in consequence of a complete absorption of serum antibodies by both Istrica and Sejroe antigens (hereafter marked as Sejroe or Istrica infections). This can be explained by a very close antigenic relationships of the strains of both serovars as they have six common main ("major") antigens (in MAT strongly reacting surface agglutinogens) and differ only by one main antigen what was determined by factor analysis performed on with rabbit antisera (13). Apparently, in some individual cases such antigenic composition might not allow an evident serovar discrimination.

It is a matter of interest that serum antibodies of another patient (a pensioner whose contact with cattle could not be ruled out) were entirely and regularly absorbed by leptospires of Hardjo serovar but to a lesser extent also by the antigens of the Istrica and Sejroe serovars in repeated AATs (Tab. 2). Probably these results indicate a Hardjo infection but they do not permit a definitive conclusion. Therefore this patient was not included in the 1st group of patients.

An unexpected finding was that the serum antibodies of the last patient were not absorbed in repeated AATs with any of the used Leptospira antigens (results not shown). In this case it cannot be excluded that the illness might have been caused by a strain belonging to a serovar of the Sejroe serogroup not detected in the country till now.

All four persons of the 1st group with detected Hardjo infection were dairy farm workers what indicate their professional exposition. This is in agreement with the fact that the maintenance hosts of Hardjo leptospires are dairy cattle.

Tab. 1. Results of AATs in a patient with Hardjo leptospirosis.

\begin{tabular}{|c|c|c|c|c|c|}
\hline \multirow{2}{*}{$\begin{array}{l}\text { Serum absorbed } \\
\text { with Leptospira } \\
\text { antigens }\end{array}$} & \multicolumn{5}{|c|}{ MAT with Leptospira strains (serovars) } \\
\hline & $\begin{array}{c}\text { M } 84 \\
\text { (Sejroe) }\end{array}$ & $\begin{array}{c}\text { Bratislava } \\
\text { (Istrica) }\end{array}$ & $\begin{array}{c}\text { Mus } 24 \\
\text { (Saxkoebing) }\end{array}$ & $\begin{array}{l}493 \text { Poland } \\
\text { (Polonica) }\end{array}$ & $\begin{array}{c}\text { Grossbeeren } \\
\text { (Hardjo)* }\end{array}$ \\
\hline- & 6400 & 6400 & 800 & 1600 & 12800 \\
\hline M 84 & 200 & 200 & $<100$ & 1600 & 6400 \\
\hline Bratislava & 800 & 100 & $<100$ & 800 & 3200 \\
\hline Mus 24 & 6400 & 1600 & $<100$ & 1600 & 12800 \\
\hline 493 Poland & 6400 & 3200 & $<100$ & $<100$ & 12800 \\
\hline
\end{tabular}

Serum titres expressed as reciprocals of serum dilutions, * genetic subtype Hardjobovis 
Tab. 2. Results of AATs in a patient with a presumed Hardjo leptospirosis.

\begin{tabular}{|c|c|c|c|c|c|}
\hline \multirow{2}{*}{$\begin{array}{l}\text { Serum absorbed } \\
\text { with Leptospira } \\
\text { antigens }\end{array}$} & \multicolumn{5}{|c|}{ MAT with Leptospira strains (serovars) } \\
\hline & $\begin{array}{c}\text { M } 84 \\
\text { (Sejroe) }\end{array}$ & $\begin{array}{c}\text { Bratislava } \\
\text { (Istrica) }\end{array}$ & $\begin{array}{c}\text { Mus } 24 \\
\text { (Saxkoebing) }\end{array}$ & $\begin{array}{l}493 \text { Poland } \\
\text { (Polonica) }\end{array}$ & $\begin{array}{c}\text { Grossbeeren } \\
\text { (Hardjo) }\end{array}$ \\
\hline- & 6400 & 3200 & 1600 & 1600 & 3200 \\
\hline M 84 & $<100$ & $<100$ & $<100$ & $<100$ & $100-400$ \\
\hline Bratislava & 100 & $<100$ & $<100$ & $<100$ & $200-800$ \\
\hline Mus 24 & 3200 & 3200 & $<100$ & 200 & 3200 \\
\hline 493 Poland & 3200 & 3200 & $<100$ & $<100$ & 3200 \\
\hline Grossbeeren & $<100$ & $<100$ & $<100$ & $<100$ & $<100$ \\
\hline
\end{tabular}

As in Table 1

Concerning the 2 nd group of patients, it should be stressed that leptospirosis of all of them (except for the one presumed Hardjo case mentioned above), inclusive three dairy farm workers, was unequivocally caused by Leptospira strains belonging to other than the Hardjo serovar of the Sejroe serogroup even though their sera also strongly reacted in MAT with Hardjo leptospires. This finding confirms once more the fact that even a high MAT titre of an unabsorbed serum cannot serve as criterion for a determination of the causal serovar of the illness.

All these 16 patients with the exception of three of them were villagers. More detailed data especially about their home activities were not at our disposal; however, it can be justifiably supposed that all these persons might have been in contact with excreta of either small rodents or domestic animals which are in Slovakia the maintenance hosts of leptospires belonging to different serovars including those of the Sejroe serogroup.

\section{Sera of small terrestrial mammals}

The sera of fourty-four small animals examined by MAT for the presence of Leptospira antibodies gave negative results except for two which reacted with serovar Grippotyphosa strains. These findings are in accordance with the older results that small terrestrial mammals are not the hosts of the serovar Hardjo leptospires (14).

\section{Dairy cattle sera}

In connection with the detected human Hardjo disease among the dairy-workers on the dairy farms the question raised whether this infection can also be find out among dairy cattle. That is why suitable sera of 15 dairy-cattle (with sufficiently high titres of antibodies) were also examined by AATs. In nine of them an evident Hardjo infection was confirmed as their serum antibodies were completely absorbed only by the antigen prepared from the strain of this serovar (Tab. 3). Eight of these nine sera were taken on the farms where the four dairy workers affected by Hardjo infection were employed and one serum was sent from the farm $\mathrm{F}$ where no human overt leptospirosis was recorded at that time (Tab. 4). Possibly, this animal indicate that Hardjo infection might also have occurred in cows on other dairy farms than were the farms A-D.

In the remaining six animals the discrimination between Hardjo, Istrica and Sejroe infections using AATs was unsuccessful since their serum antibodies were absorbed with the antigens of more than one serovar, i.e. $1 \mathrm{x}$ with Istrica and Sejroe antigens, $1 \mathrm{x}$ with Hardjo and Sejroe and $4 \mathrm{x}$ with Hardjo, Istrica and Sejroe antigens respectively. Four of these animals also originated in the same dairy farms where the Hardjo diseased patients worked. Explanation of the results obtained with the sera of all these six animals may be analogous to those obtained with patients' sera. The described findings confirm that the cow herds in the farms A-D might have been infected not only with Leptospira strains of the Hardjo serovar but also by leptospires of Istrica or Sejroe serovars; the microbes of the two last mentioned serovars are harboured in Slovakia above all by their maintenance hosts house mice (Mus musculus spp.) but also by cattle which are their incidence reservoirs.

Summing-up, out of all 14 with Hardjo strain reacting cattle sera, the AATs results obtained with nine of them confirmed unequivocally the Hardjo infection while in the remaining five sera such a clear discrimination of this infection from those caused by Istrica or Sejroe leptospires could not be achieved.

Attempts to isolate leptospires by inoculation of cattle urine in Korthof's or EMJH media were realized with a certain delay on the farms where human Hardjo infections occurred and perhaps therefore without success.

After the first Hardjo patients had been diagnosed the findings were reported to the State Veterinary and Food Administration.

Tab. 3. Results of AATs in a cow affected by Hardjo infection.

\begin{tabular}{|c|c|c|c|c|c|}
\hline \multirow{2}{*}{$\begin{array}{l}\text { Serum absorbed } \\
\text { with Leptospira } \\
\text { antigens }\end{array}$} & \multicolumn{5}{|c|}{ MAT with Leptospira strains (serovars) } \\
\hline & $\begin{array}{c}\text { M } 84 \\
\text { (Sejroe) }\end{array}$ & $\begin{array}{c}\text { Bratislava } \\
\text { (Istrica) }\end{array}$ & $\begin{array}{c}\text { Mus } 24 \\
\text { (Saxkoebing) }\end{array}$ & $\begin{array}{l}493 \text { Poland } \\
\text { (Polonica) }\end{array}$ & $\begin{array}{c}\text { Grossbeeren } \\
\text { (Hardjo) }\end{array}$ \\
\hline- & 3200 & 1600 & 3200 & 3200 & 6400 \\
\hline M 84 & $<100$ & 1600 & 800 & 800 & 1600 \\
\hline Bratislava & $<100$ & $<100$ & 1600 & 800 & 3200 \\
\hline Mus 24 & 800 & 1600 & $<100$ & $<100$ & 6400 \\
\hline 493 Poland & 400 & 400 & $<100$ & $<100$ & 1600 \\
\hline
\end{tabular}

As in Table 1 
Tab. 4. Leptospirosis diagnosed by AATs on serovar level in patients and cows.

\begin{tabular}{|c|c|c|}
\hline $\begin{array}{l}\text { Farm } \\
\text { Region of the country }\end{array}$ & $\begin{array}{l}\text { Patients (with Hardjo infection *) } \\
\text { Profession, (age), illness }\end{array}$ & $\begin{array}{c}\text { Dairy cattle } \\
\text { No of animals, causal serovar(s) }\end{array}$ \\
\hline $\begin{array}{l}\text { A } \\
\text { Western Slovakia }\end{array}$ & Dairy man (29), fever, meningitis* & $2 \times$ Hardjo \\
\hline $\begin{array}{l}\text { B } \\
\text { Middle Slovakia }\end{array}$ & $\begin{array}{l}\text { Dairy maid (37), fever, meningeal irrita- } \\
\text { tion* }\end{array}$ & $2 \times$ Hardjo \\
\hline $\begin{array}{l}\mathrm{C} \\
\text { Eastern Slovakia }\end{array}$ & Dairy maid (54), fever * & $\begin{array}{l}3 \times \text { Hardjo } \\
1 \times \text { Hardjo or Sejroe or Istrica }\end{array}$ \\
\hline $\begin{array}{l}\mathrm{D} \\
\text { Western Slovakia }\end{array}$ & Dairy maid (47), subclinical infection?* & $\begin{array}{l}1 \times \text { Hardjo } \\
1 \times \text { Hardjo or Sejroe } \\
2 \times \text { Hardjo or Sejroe or Istrica }\end{array}$ \\
\hline $\begin{array}{l}\text { E } \\
\text { Western Slovakia }\end{array}$ & None $* *$ & $1 \times$ Sejroe or Istrica \\
\hline $\begin{array}{l}\text { F } \\
\text { Western Slovakia }\end{array}$ & None $* *$ & $1 \times$ Hardjo \\
\hline $\begin{array}{l}\mathrm{G} \\
\text { Western Slovakia }\end{array}$ & None $* *$ & $1 \times$ Hardjo or Sejroe or Istrica \\
\hline
\end{tabular}

**In other 16 patients no Hardjo infection was detected, ${ }^{+}$Serum agglutinins absorbed by Leptospira strains belonging to two or three Sejroe group serovars

The epizootologist of this office ordered to realize on the relative farms clinical examination of the cattle and to collect the blood specimens; a part of them was finally examined in the authors' laboratory. No clinical signs of leptospirosis were found in herds of examined animals even though the Hardjo infection causes pregnant failures or reduced conception rates in infected cows (15). On the other hand, there was also described the possibility that the clinical manifestation of this infection in cattle may often go unnoticed $(16-18)$. Perhaps the serologically identical Leptospira strains of this serovar may possess different biological properties. Existence of two different strains of the Hardjo serovar from the point of view of their pathogenicity was suggested many years ago. According to some authors, there can exist strains which cause severe meningeal form in humans and abortion in cattle while other strains brought on a milder flu-like illness in men and only mastitis in cattle. This finding was not confirmed in experimentally infected grivet monkeys (19).

\section{Conclusion}

The present study brought about the knowledge that AATs may be used for diagnostics of human Sejroe leptospirosis (sensu lato) on serovar level. This is in agreement with our former findings obtained by using AATs for such a diagnostics of leptospiral diseases caused by leptospires of other serogroups $(10-12)$. To the best of our knowledge, this methodical approach was not used by other authors till now. Probably, because the realization of a serum absorption is a little delicate procedure requiring sufficient experience of the laboratory worker. In the present study, the method allowed to distinguish in men not only Hardjo infections but also those of Istrica and Sejroe from each other. Unequivocal results on serovar level were achieved approximately in $2 / 3$ of examined human and in $3 / 5$ of dairy cattle specimens (i.e. 12 out of 19 human and 9 out of 15 cattle sera respectively). In the rest of the sera the effort was not successful apparently because of the close antigenic relations of leptospires of these serovars or due to a slightly different antibody formation both in individual patients and animals. In spite of this, AATs may be a useful tool for detection of a Hardjo infection and in consequence of this for determination of appropriate epidemiological and epizootological measures especially on farms where dairy workers are in contact with dairy cattle.

\section{References}

1. Belmaker I, Alkan M, Barnea A, Dukhan L, Yitzmaki S, Gross. Risk of transmission of leptospirosis from infected cattle to dairy workers in southern Israel. Isr Med Assoc J; 2004; 6 (1): 24-27.

2. Little TWA, Stevens AE, Hathaway SC. Serological studies of British leptospiral isolates. III. The distribution of leptospires of the Sejroe serogroup in the British Isles. Epidem Inf 1987; 99: 117-126.

3. Colgan M, Eivers B Jr, Egan J. An unrecognised zoonosis? Leptospirosis hardjo in man in the Republic of Ireland. Irl Med J 1984; 77 (8): 238-240.

4. Crevantin D, Banfi E, Crotti D, Cinco M. Serosurvey of the presence of leptospiral agglutinins in humans in Northen Italy. Eur J Epidemiol 1986; 2 (1): 44-47.

5. Terpstra WJ, Korver H, Schönemann C, Gravekamp C. Weil's disease, milker's fever and other leptospirosis, 1981 - 1987 (in Dutch). Ned Tijdschr Geneeskd 1989; 133 (26): 1322-1326.

6. Peoppl W, Orola MJ, Herkner H et al. High prevalence of antibodies against Leptospira spp.in male Austrian adults: a cross-sectional survey, April to June 2009. Euro Surveill 2013; 18 (25). doi: pii:20509

7. De la Pena-Moctezuma A, Bulach DM, Kalambaheti I, Adler B. Comparative analysis of the LPS biosynthetic loci of the genetic subtypes of serovar Hardjo: Leptospira interrogans subtype Hardjoprajitno and Leptospira borgpeterseni subtype Hardjobovis. FEMS Microbiol Lett 1999; 177 (2): 319-326.

8. Kmety E. Faktorenanalyse von Leptospiren der Icterohaemorrhagiae und einiger verwandter Serogruppen. Bratislava: Vydav Slov Akad Vied, 1967: 1-124. 


\section{1-176}

9. World Health Organization. Current problems in leptospirosis research. Geneva:Techn Rep Series No 380. 1967: 1-32.

10. Kmety E, Bakoss P. Zur Serotypendiagnostik der Leptospirosen. 39-47. In: Nauman G, Köhler B (Eds). Symposium Anläßlich des 100. Geburtstages von Johannes Kathe am 5. Februar1981. Rostock: Wisseschaftspublizistik W Pieck Universität 1982.

11. Bakoss P, Kmety E. To the importance of absorption tests in the serotype diagnosis of leptospirosis in humans (In Slovak). Čs Epidemiol (Prague) 1980; 29 (3): 165-170.

12. Bakoss P, Awad-Masalmeh M, Resch G, Jareková J, Stanko M, Perželová J Human Mozdok leptospirosis first diagnosed by serum agglutinin-absorption tests in the Slovak Republic. Epidemiol Mikrobiol Imunol (Prague) 2018; 67 (3): 114-120.

13. Kmety E. Study of the antigenic structure of the leptospirae. Classification of the serological group Hebdomadis. Folia Fac Med Univ Comenianae Bratislavensis 1977; 15 (2): 245-309.

14. Kuiken T, van Dijk JE, Terpstra WJ, Bokhout BA. The role of the common vole (Microtus arvalis) in the epidemiology of bovine infection with Leptospira interrogans serovar hardjo infection. Veter Microbiol 1991; $28: 356$.
15. Dhaliwal GS, Murray RD, Dobson H, Montgomery J, Ellis WA. Reduced conception rates in dairy cattle associated with serological evidence of Leptospira interrogans serovar hardjo infection. Vet Rec 1996; 139 (5): 110-113.

16. 16. Bahaman AR, Marshal RB, Hellstrom JS. A serological study of bovine leptospirosis in the district of Taranaki. NZ Vet J 1984; 32 (8): 134-136.

17. Ngbede EO, Raji MA, Kwanasjie CN, Okolocha EC. Serosurvey of Leptospira spp serovar Hardjo in cattle from Zaria, Nigeria. Revue Méd Vét 2013; 164 (2): 85-89.

18. McLean M, Ruscoe Q, Kline T, King C, Nesdale A. A cluster of three cases of leptospirosis in dairy farm workers in New Zealand. NZ Med J 2014; 127 (1388): 13-20.

19. Palmer MF, Waitkins SA, Fitzgeorge RB, Baskerville A. Experimental infection of monkeys with leptospira interrogans serovar hardjo. Epidemiol Infect 1987; 98 (2): 191-197.

Received December 5, 2018. Accepted January 14, 2019. 